\title{
Successful Assessment Strategies for ABET Accreditation of Engineering Programs Offered at Different Campuses
}

Hermes E. Calderón, PhD, Ramón E. Vásquez, PhD, Diego A. Aponte, MSc, and Maritza Del Valle, PhD Caribbean

University, Puerto Rico, hcalderon@caribbean.edu,ravazquez@caribbean.edu,diaponte@caribbean.edu,

mvalle@caribbean.edu

\begin{abstract}
Administrators of engineering programs across the board have increased their interest to obtain accreditation. The Accreditation Board for Engineering and Technology (ABET) is one of the organizations more recognized at a global level, not only for quality assurance but also because the accreditation criteria help the programs to set continuous improvement processes. However, there is not useful information or guidelines for programs seeking ABET accreditation for the first time in programs offered at different locations. This paper presents the assessment plan and strategies to prepare programs to a successful accreditation, in programs offered in different campuses, for an eventual on-site visit. Dissemination of results, summary of materials for the display room, and successful practices in order to improve the programs, are included as well. In this document, we highlight the use of educational platforms as low cost assessment tools that many institutions already have.

Keywords-Engineering Accreditation, Educational Platform, Assessment Strategies, Continuous Improvement.
\end{abstract}

Digital Object Identifier

(DOI):http://dx.doi.org/10.18687/LACCEI2016.1.1.226

ISBN: 978-0-9822896-9-3

ISSN: 2414-6390

$14^{\text {th }}$ LACCEI International Multi-Conference for Engineering, Education, and Technology: "Engineering Innovations for Global Sustainability", 20-22 July 2016, San José, Costa Rica. 


\title{
Successful Assessment Strategies for ABET Accreditation of Engineering Programs Offered at Different Campuses
}

\author{
Hermes E. Calderón, PhD, Ramón E. Vásquez, PhD, Diego A. Aponte, MSc, and Maritza Del Valle, PhD \\ Caribbean University, Puerto Rico, hcalderon@caribbean.edu, ravazquez@caribbean.edu, diaponte@caribbean.edu, \\ mvalle@caribbean.edu
}

\begin{abstract}
Administrators of engineering programs across the board have increased their interest to obtain accreditation. The Accreditation Board for Engineering and Technology (ABET) is one of the organizations more recognized at a global level, not only for quality assurance but also because the accreditation criteria help the programs to set continuous improvement processes. However, there is not useful information or guidelines for programs seeking ABET accreditation for the first time in programs offered at different locations. This paper presents the assessment plan and strategies to prepare programs to a successful accreditation, in programs offered in different campuses, for an eventual on-site visit. Dissemination of results, summary of materials for the display room, and successful practices in order to improve the programs, are included as well. In this document, we highlight the use of educational platforms as low cost assessment tools that many institutions already have.

Keywords-Engineering Accreditation, Educational Platform, Assessment Strategies, Continuous Improvement.
\end{abstract}

\section{INTRODUCTION}

In 1980, the Engineers' Council for Professional Development (ECPD) was renamed the Accreditation Board form Engineering and Technology (ABET) to more accurately describe their emphasis on accreditation. It is a not-for-profit, non-governmental accrediting agency used to evaluate all American engineering programs to ensure that a college or university program, not institutions, meets the quality standards of the profession for which that program prepares graduates [1]. The accreditation criteria used by ABET, have been discussed extensively for all the U.S. universities in order to align their engineering programs curriculum to meet all the ABET requirements. In some cases, it is necessary re-design or develop a new curriculum for a specific program to achieve ABET accreditation [2].

All engineering programs with interest in ABET accreditation must demonstrate that they satisfy the following accreditation criteria for baccalaureate level, which may change from one accreditation cycle to the next: Criterion 1 (students), Criterion 2 (program educational objectives), Criterion 3 (student outcomes), Criterion 4 (continuous improvement), Criterion 5 (curriculum), Criterion 6 (faculty), Criterion 7 (facilities), Criterion 8 (institutional support) [3].

Criterion 3 is the most discussed in the literature because the programs must have documented student outcomes that prepare graduates to attain the Program Educational Objectives (PEOs) and show the relationship of the minimum student outcomes established by ABET with the PEOs. For that reason, it is common to adopt the minimum student outcomes established by the Engineering Accreditation Commission (EAC) presented in Table I.

TABLE I. Student Outcomes are outcomes (a) through (k) plus any additional outcomes that may be articulated by the program [3].

\begin{tabular}{|l|l|}
\hline \multicolumn{2}{|c|}{ Student Outcomes } \\
\hline a & $\begin{array}{l}\text { an ability to apply knowledge of mathematics, science and } \\
\text { engineering }\end{array}$ \\
\hline b & $\begin{array}{l}\text { an ability to design and conduct experiments, as well as to analyse } \\
\text { and interpret data }\end{array}$ \\
\hline c & $\begin{array}{l}\text { an ability to design a system, component, or process to meet desired } \\
\text { need within realistic constrains such as economic, environmental, } \\
\text { social, political, ethical, health and safety, manufacturability, and } \\
\text { sustainability }\end{array}$ \\
\hline d & an ability to function on multidisciplinary teams \\
\hline e & an ability to identify, formulate, and solve engineering problems \\
\hline f & an understanding of professional and ethical responsibility \\
\hline g & an ability to communicate effectively \\
\hline h & $\begin{array}{l}\text { the broad education necessary to understand the impact of engineering } \\
\text { solutions in a global, economic, environmental, and societal context }\end{array}$ \\
\hline i & $\begin{array}{l}\text { a recognition of the need for, and an ability to engage in life-long } \\
\text { learning }\end{array}$ \\
\hline j & a knowledge of contemporary issues \\
\hline k & $\begin{array}{l}\text { an ability to use the techniques, skills, and modern engineering tools } \\
\text { necessary for engineering practice }\end{array}$ \\
\hline
\end{tabular}

An overview of the accreditation process and the description of instructional techniques to prepare students to achieve student outcomes (a-k), corresponding to Criterion 3 for engineering accreditation, were presented by Felder [4]. However, literatures about the strategies to obtain ABET accreditation for an engineering program offered in different cities by a same institution is not available.

Strategies to assess and evaluate programs offered in more than one location, description of curricula review process to meet constituency and accreditation requirements, assessment instruments, and assessment strategies, are presented on this paper. This work could be useful to prepare other institution to meet all the EAC requirements on the ABET accreditation process to achieve a successful accrediting program offered in more than one location in an eventual ABET visit. 


\section{PROGRAM CRITERIA}

Each program to be evaluated must satisfy applicable program criteria, which are determined by the technical specialties indicated by the title of the program. The areas of curricular topics and faculty qualifications are requirements stipulated in the program criteria [3]. For baccalaureate level programs, all engineering programs seeking accreditation must demonstrate that they satisfy eight criteria, which was mentioned in previous section. In the following sections, the authors present some recommendations to be considered:

\section{A. Program Educational Objectives}

Criterion 2 presents the PEOs. In this section, the program must describe:

- How the PEOs align with the institution's vision and mission.

- How the PEOs are documented and systematically utilized.

- How the PEOs are revised periodically.

\section{B. Student Outcomes}

Criterion 3 presents the student outcomes. In this section, the program must document the student outcomes that prepare graduates to attain the PEOs. Each engineering program might adopt the minimum students outcomes required by ABET (a through k) that was mentioned before in Table I, however, its recommended that each program could review and define their own student outcomes.

\section{DESIGN AN ASSESSMENT PLAN}

The assessment plan must be developed considering that the implementation impacts the locations where the engineering programs are offered, especially if the programs are in more than one location. Therefore, the assessment plan established the duties of the faculty, in such a way that the assessment tasks are fulfilled in all locations. The implementation of this plan should begin with the establishment of an Accreditation Committee to lead the accreditation process. This committee should be composed by the programs coordinators and Institution administrators. With the aid of the faculty, they should revise the minimum student outcomes defined by ABET identifying compliance and deciding what outcomes will be adopted according to criterion 3 , as a starting point for the assessment process. Each program should be reviewed, if needed, for additional student outcomes. The minimum student outcomes must be established for the engineering program offered by the Institution.

In summary, the assessment process at program level could be divided in two parts. The assessment structure (grey boxes in Fig 1), in which the review of the program criteria is the starting point, includes the definition of the student outcomes and its alignment with the PEOs and Institutional goals, a curricular map and the selection of an assessment period to collect data. The second part focuses in the implementation of the assessment tasks to assess the student's performance (white boxes in Fig 1). It includes a sample of course material, which is performed through a course portfolio, and the tabulation of assessment results. Next sections present an overview of some assessment components.

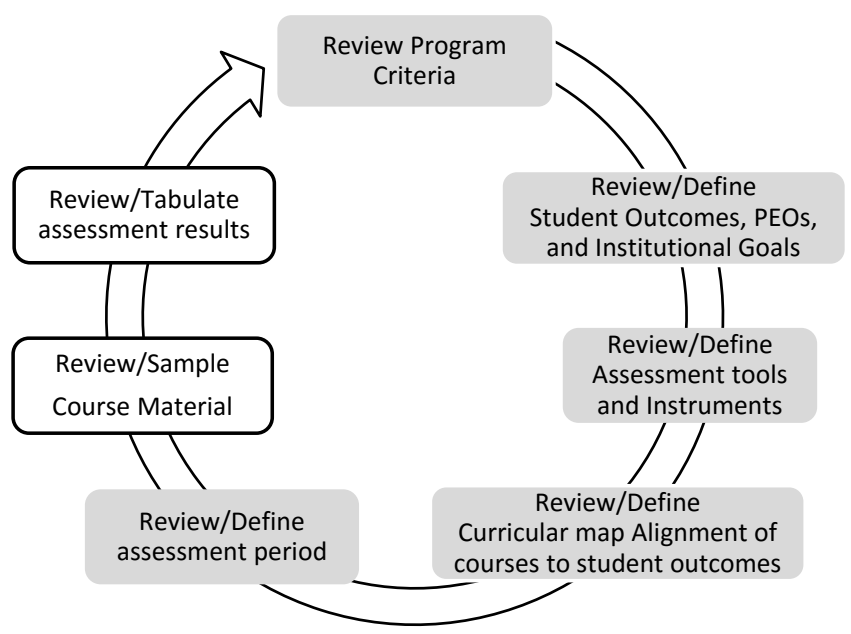

Fig. 1 Assessment Process.

\section{A. Curricular MAP}

A program must show the relationship of the student outcomes to the courses in their curriculum. Table II and Table III below establish that each outcome should be assessed at three levels through the Engineering curriculum; assessing the outcome at an introductory level (I), i.e. freshman or sophomore, assessing the outcome at an intermediate level (R), i.e. junior, where the outcome is reinforced (R), assessing the outcome at an advanced level (E), i.e. senior, where the student outcome is emphasized (E). We implement a divided curriculum map in five parts: (a) Table with the relationship between student outcomes to general courses; (b) Table with the relationship between student outcomes to core courses; (c) Table with the relationship between student outcomes to general engineering courses; (d) Table with the relationship between student outcomes to concentration courses; (e) Table with the relationship between student outcomes to engineering elective courses. Table II illustrates an example of the relationship between student outcomes to general courses while Table III shows an example of the relationship between student outcomes to concentration courses.

TABLE II. Example of relationship between student outcomes and some general courses

\begin{tabular}{|l|l|l|l|l|l|l|l|l|l|l|l|l|}
\hline \multicolumn{1}{|c|}{ RELATIONSHIP OF STUDENT OUTCOMES TO GENERAL COURSES } \\
\hline
\end{tabular}

$14^{\text {th }}$ LACCEI International Multi-Conference for Engineering, Education, and Technology: "Engineering Innovations for 
TABLE III. Example of relationship of student outcomes to some concentration courses

\begin{tabular}{|c|c|c|c|c|c|c|c|c|c|c|c|c|}
\hline \multicolumn{13}{|c|}{$\begin{array}{l}\text { RELATIONSHIP OF STUDENT OUTCOMES TO } \\
\text { CONCENTRATION COURSES }\end{array}$} \\
\hline \multirow{2}{*}{\multicolumn{2}{|c|}{ Courses }} & \multicolumn{11}{|c|}{ Student Outcomes } \\
\hline & & $a$ & $b$ & $c$ & $d$ & $e$ & $f$ & $g$ & $h$ & $i$ & $j$ & $\boldsymbol{k}$ \\
\hline ELEN-1 & $\begin{array}{l}\text { Electrical Circuits } \\
\text { Analysis I }\end{array}$ & $\mathrm{R}$ & $\mathrm{R}$ & & $\mathrm{R}$ & & & & & & & $\mathrm{R}$ \\
\hline ELEN-2 & Logic Circuits I & $\mathrm{R}$ & $\mathrm{R}$ & $\mathrm{R}$ & & $\mathrm{R}$ & & & & & & \\
\hline ELEN-3 & Elec. Power Transmission & $\mathrm{E}$ & $\mathrm{E}$ & & & $\mathrm{E}$ & & & & & $\mathrm{R}$ & $\mathrm{R}$ \\
\hline ELEN-4 & Control Engineering & $\mathrm{E}$ & $\mathrm{E}$ & E & $\mathrm{R}$ & $\mathrm{E}$ & $\mathrm{R}$ & E & & E & $\mathrm{R}$ & $\mathrm{E}$ \\
\hline
\end{tabular}

\section{B. Assessment Instruments}

The accreditation committee evaluates the selected tools and instruments to gather information to assess student outcomes. Table IV shows assessment tools and instruments for the assessment process:

TABLE IV. Assessment Instruments

\begin{tabular}{|c|c|c|c|c|}
\hline $\begin{array}{c}\text { Assessment } \\
\text { Tool }\end{array}$ & Instruments & Assess & Strengths & Limitations \\
\hline \multirow{2}{*}{$\begin{array}{c}\text { Course } \\
\text { portfolio }\end{array}$} & Rubrics & $\begin{array}{c}\text { Student } \\
\text { outcome }\end{array}$ & $\begin{array}{c}\text { Direct, } \\
\text { quantitative }\end{array}$ & None \\
\cline { 2 - 5 } & Appraisal & Course & Indirect & $\begin{array}{c}\text { Indirect, } \\
\text { Qualitative }\end{array}$ \\
\cline { 2 - 5 } & $\begin{array}{c}\text { Other course } \\
\text { evidence }\end{array}$ & Course & $\begin{array}{c}\text { Supporting } \\
\text { reference }\end{array}$ & $\begin{array}{c}\text { Faculty } \\
\text { load }\end{array}$ \\
\hline Survey & $\begin{array}{c}\text { Graduation } \\
\text { survey }\end{array}$ & $\begin{array}{c}\text { Student } \\
\text { outcome }\end{array}$ & $\begin{array}{c}\text { At graduation } \\
\text { time }\end{array}$ & $\begin{array}{c}\text { Indirect, } \\
\text { Qualitative }\end{array}$ \\
\hline
\end{tabular}

\section{Design Rubrics}

Rubrics allow quantitative analysis of the student outcomes. Therefore, rubric's adaptation and standardization process is part of the assessment, and it is essential to calibrate these instruments to collect information in the most accurate way. Rubrics include performance indicators, which must be aligned with the levels the outcomes are accessed. Rubrics must be revised and amended (if required) after finishing each cycle of assessment. With the standardization of the instruments initiate a process of continuous improvement, a process that contemplates the development of workshops to orient faculty regarding the administration and revision of rubrics. The rubric instruments must be available in the display room for the onsite visit, to serve as a reference.

\section{Graduation Survey}

Graduation Survey collects the students' perceptions of the attainment of the student outcomes. The survey is a questionnaire fill out by the graduating student before commencement. The data must be gathered yearly. The Graduation Surveys and results analysis must be available for review in the display room for the on-site visit.

\section{E. Self-Appraisal Survey}

Self-Appraisal Survey collects the students' perceptions of both the topics required by a specific course, compiled in the
Self-Appraisal Course Initial Survey (SACIS), and the knowledge of the topics covered in class, compiled in the SelfAppraisal Course Exit Survey (SACES). Both surveys are questionnaires filled out by the student before and after taking a course. The Self-Appraisal Surveys are included in the course portfolio and allow faculty to follow up the required strategies to improve the student performance.

\section{F. Course Portfolio}

Course Portfolio is an assessment tool that the professor uses to compile all the assessment activities of the course he or she is teaching. At the end of each academic term, the professor is responsible to turn in the course portfolio as assigned in the sampling cycle. Course portfolios must be available in the display room for the on-site visit.

\section{G. Other Course Evidence}

Professors gathered evidence from other activities, including examples of the evaluation and all material that documents the attainment of the student outcomes. This information should be included in the course portfolio.

\section{H. Assessment Period}

Once the instruments are developed, the implementation of the assessment process could be started and must be periodic in order to allow continuous improvement. The periodic cycle of assessment must begin and finish before one student graduates, which results in assessment cycles less than 4 years, since almost all baccalaureates in engineering programs offered at universities in the United States are 4 to 5 years programs. Two years is a recommended number because an engineering program will be able to evaluate the results of the first cycle and implement the improvement actions during the second cycle. Thus, the student performance is assessed at least twice before their graduation. For reference, Fig. 2 illustrates a continuous improvement process.

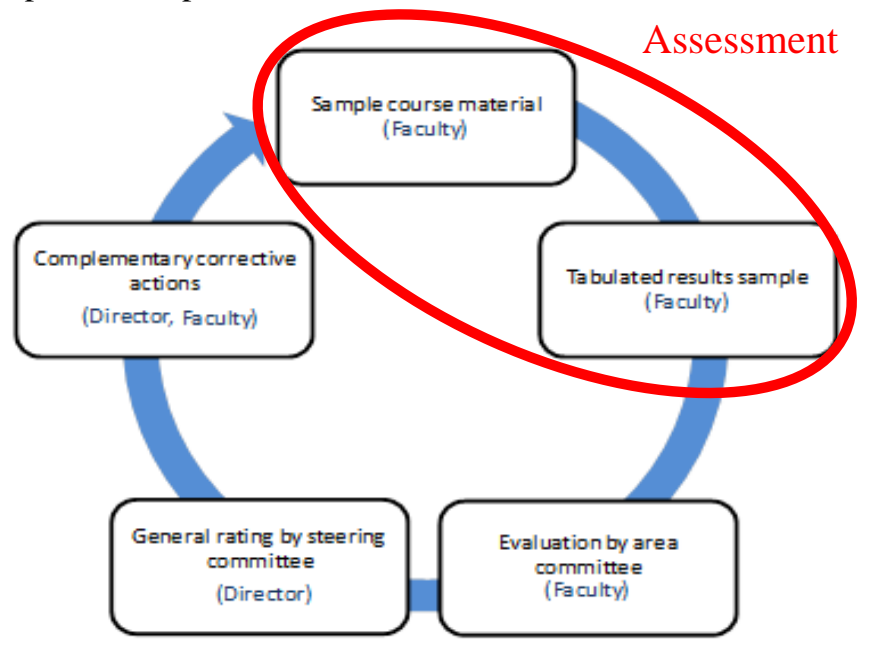

Fig. 2 Continuous Improvement Process.

$14^{\text {th }}$ LACCEI International Multi-Conference for Engineering, Education, and Technology: "Engineering Innovations for Global Sustainability”, 20-22 July 2016, San José, Costa Rica. 


\section{Alternatives for Programs Seeking Accreditation}

When a program is seeking accreditation, and it does not have an assessment process, it could implement a pilot program of one year assessment period. The measurement of each of the student outcomes in the major courses must be scheduled and such results will provide the starting point (base line) of student outcomes. Being the first time that the student outcomes would be evaluated, a performance goal not less than $60 \%$ of students meeting the outcome could be set. To ensure a systematic process, the collection of data from courses must be focused on the submission of the portfolios as described in the assessment plan. The turn in of portfolios is programmed for the beginning of the next academic term in which the evaluation is conducted.

After the first year, the length of the assessment cycle could be modified to set periods of 2 or 3 years to assess the student outcomes. Thus, two or three student outcomes would be measured per academic term. Table V shows an example of data collection for student outcomes, including a first and two years subsequent cycle.

TABLE V. Example of schedule for data collection of student outcomes

\begin{tabular}{|c|c|c|c|c|c|c|}
\hline \multirow{2}{*}{$\begin{array}{c}\text { Student } \\
\text { Outcome }\end{array}$} & \multicolumn{2}{|c|}{ 2015-2016 } & \multicolumn{2}{c|}{ 2016-2017 } & \multicolumn{2}{c|}{ 2017-2018 } \\
\hline & Fall & Spring & Fall & Spring & Fall & Spring \\
\hline $\mathrm{a}$ & $\mathrm{x}$ & & $\mathrm{x}$ & & & \\
\hline $\mathrm{b}$ & & $\mathrm{x}$ & & $\mathrm{x}$ & & \\
\hline $\mathrm{c}$ & $\mathrm{x}$ & & & & $\mathrm{x}$ & \\
\hline $\mathrm{d}$ & & $\mathrm{x}$ & & & & $\mathrm{x}$ \\
\hline $\mathrm{e}$ & $\mathrm{x}$ & & $\mathrm{x}$ & & & \\
\hline $\mathrm{f}$ & & $\mathrm{x}$ & & $\mathrm{x}$ & & \\
\hline $\mathrm{g}$ & $\mathrm{x}$ & & & & $\mathrm{x}$ & \\
\hline $\mathrm{h}$ & & $\mathrm{x}$ & & & & $\mathrm{x}$ \\
\hline $\mathrm{i}$ & $\mathrm{x}$ & & $\mathrm{x}$ & & & \\
\hline $\mathrm{j}$ & & $\mathrm{x}$ & & $\mathrm{x}$ & & \\
\hline $\mathrm{k}$ & $\mathrm{x}$ & & & & $\mathrm{x}$ & \\
\hline
\end{tabular}

To ensure improvement of the process it's important to assess and evaluate it. Therefore, a schedule for the review of instruments and methods would be necessary. An example of the schedule for review the assessment and evaluation processes is included in Table VI.

TABLE VI. Schedule for review the assessment and evaluation processes

\begin{tabular}{|l|c|c|c|}
\hline Schedule for review the assessment and evaluation processes for each \\
student outcome
\end{tabular}

\section{ASSESSMENT STRATEGIES FOR MORE THAN ONE LOCATION}

One of the questions that an administrator has to resolve is: if you have the same curricula offering in more than one site or campus, is it necessary to submit more than one application for program evaluation or is it possible to submit an uniquely process for the program?, the answer depends on how the program license is defined at the local state board. If you have different licensing for each campus, it will require different processes, but if there is a unique program license to offer the same curricula at different campuses, it will require the submission of only one application. In the latter case, program administrators have to pay attention on the assessment strategies to ensure compliance with the different criteria and equivalency between different campuses. Sections A to D present some strategies that were employed by the engineering programs at $\mathrm{CU}$ and the authors recommend to implement them in other sites.

\section{A. Course Design Project Guide}

With the same program in different campuses, different faculty could teach the same courses. Although the courses use the same syllabus, assignments and projects could differ in complexity or depth due to the faculty's perspective. To ensure the same level of complexity and depth at different campuses, faculty teaching the courses might work together to develop project guides.

Moreover, for design courses, a design project guide must be implemented to guarantee the same level of rigor for the project's scope in different campuses, ensuring the attainment of related specific student outcomes. These guides must define objectives, problem identification, scope of work, requirements, related course learning outcomes and student outcomes. Each professor should work on the project design guides for design courses and establish communication with faculties of the same technical area (i.e. Structures).

Faculty also should follow up the student's work very closely to ensure success, promoting interdisciplinary work and tracking the different tasks into the project to evaluate the individual contribution

\section{B. Capstone Conferences for Major Design Courses}

Assessment of capstone projects is critical as an evidence of the attainment of the engineering student outcomes. All engineering programs must emphasize the strategies to ensure a major design experience and its corresponding assessment. An innovative way of integrating general education outcome into a capstone senior design course was presented by Mourtos [5]. He uses an aerospace engineering design work to demonstrate the feasibility of the concept.

A capstone design project requires creative activity and thinking. All student outcomes at the program level are mostly mapped in the learning outcomes of capstone projects, making

$14^{\text {th }}$ LACCEI International Multi-Conference for Engineering, Education, and Technology: "Engineering Innovations for Global Sustainability", 20-22 July 2016, San José, Costa Rica. 
difficult the evaluations of student performance and project qualities in addition to assessing student outcomes. For these reason, universities are implementing different tools to help in the evaluation of capstone design projects. In 2012, a tool called easyCapstone was developed and implemented as a framework for managing and assess capstone design projects by Erradi, [6] . These tools will be implemented to all programs at the engineering college at Qatar University. In 2015, a unified approach for assessing capstone design projects and student outcomes in computer engineering programs was presented by Yousafzai [7]. This framework could be modified and implemented in other engineering programs.

In general, for capstone courses of all engineering programs, we recommend to include the use of grading rubrics, focus groups, faculty, and industry or external evaluators in oral presentations, as a strategy to evaluate and assess the student performance. In addition, with more than one campus, defining a capstone conference where students and faculty present and evaluate their projects result in a useful strategy. Those conferences should be open to the community and could be offered on alternate basis between campuses each semester.

\section{Online materials storage}

With the technology advances, most institutions are using online educational platforms to support instruction. These platforms might be a great tool to standardize and store assessment documentation with easy access. As a strategy, programs should prepare a space in an educational platform, available only for faculty and administrative personnel, where all assessment documentation could be organized. Thus, faculty from different campuses could access the same information at the same time. For instance, a folder in the educational platform for a specific course could be storage with relevant information such as: assessment instruments, student outcomes evidences, rubrics, syllabus, surveys, portfolios, among other resources. One example of the minimum files shared in an education platform is shown in Fig. 3. Once the assessment documentation is available in a digital form and online it's easy to prepare the materials room, as well as, any assessment report.

\section{Dissemination of Results}

Communication is a key point to obtain accreditation. The collected information in the course portfolios could be analysed during term break (i.e. summer), and dissemination of assessment results through: faculty meetings, in the educational platform, general presentations, and institutional bulletin boards, must be performed. Faculty meetings allow sharing impressions (closing the loop) to make recommendation and promote equivalence for the different campuses, setting the base for continuous improvement. On the other hand, bulletin boards facilitate sharing of assessment results with the community as required by $\mathrm{ABET}$ guidelines.

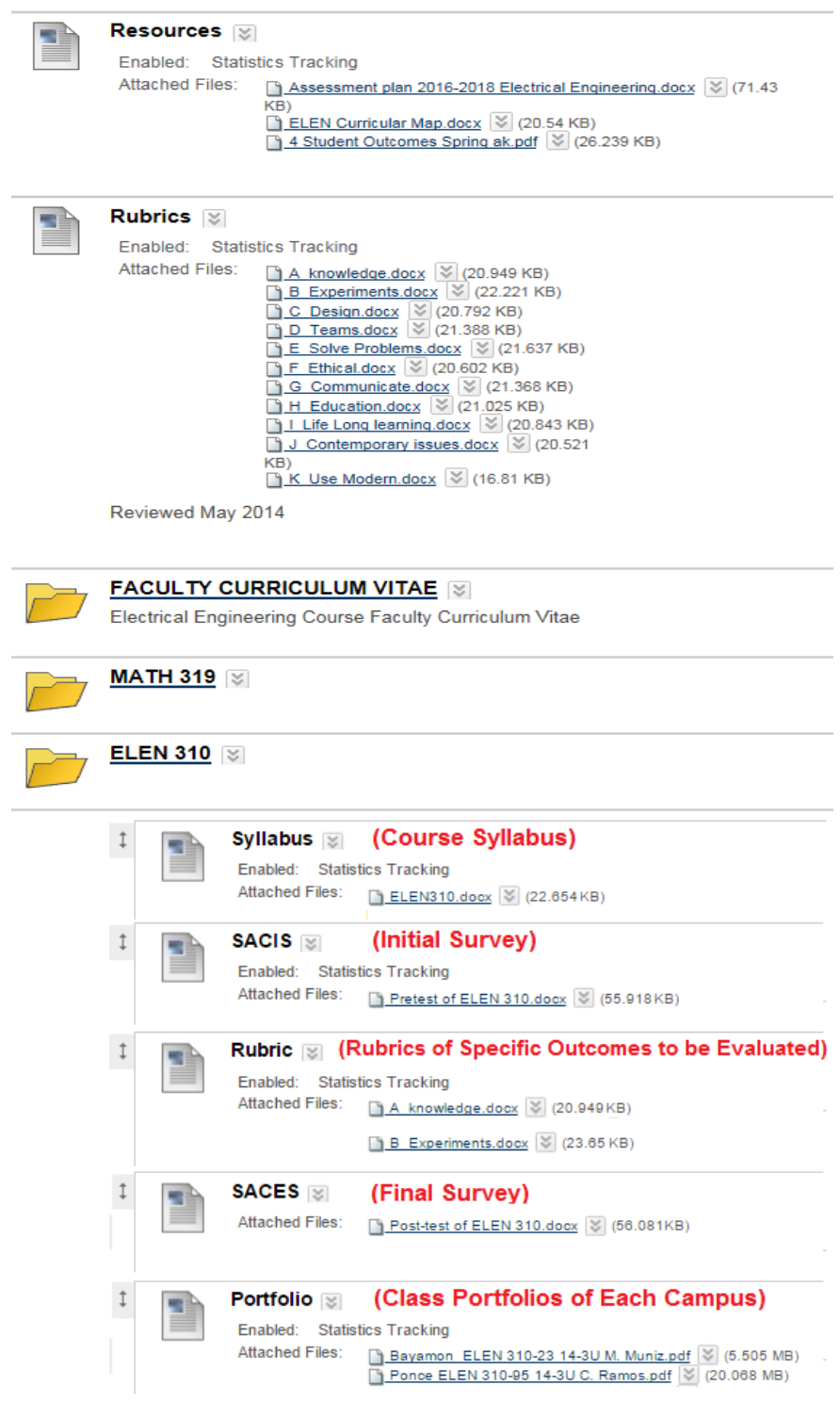

Fig. 3 Program Space on Educational Platform and Course Folder Resources

\section{SUMMARY OF THE ASSESSMENT RESULTS FOR MATERIALS ROOM}

Regardless of the way the data collected is organized and storage, it's recommended to follow the instructions of the evaluator's team chair to show the evidences through the materials room. One way is to organize the materials room and prepare a summary or portfolio for each of the student outcomes. This summary will help the program evaluators (PEV) to review the assessment documentation in support to actions taken by the program in order to improve. All relevant information supporting the attainment of the student outcomes should be in the student outcome portfolio. For reference, each student outcome portfolio prepared by the authors included a content table, the assessment data from corresponding courses (course name, performance indicator, evaluation results and corresponding evidence), recommendations and actions taken

$14^{\text {th }}$ LACCEI International Multi-Conference for Engineering, Education, and Technology: "Engineering Innovations for Global Sustainability", 20-22 July 2016, San José, Costa Rica. 
to continuous improvement. Evidence not only include all assessment activities where rubrics were employed to measure the performance indicators, but also any other project, exam problem or special assignment that help to illustrate the attainment of the student outcome.

\section{CONCLUSION}

Although ABET makes public an updated assessment and accreditation guides, many programs still have unresolved questions when looking for accreditation, knowing that the principal cause for failure is a deficiency in continuous improvement. The strategies presented in this paper have been successful in our initial accreditation process, and the authors believe it can be implemented at other programs seeking accreditation. Moreover, these practices help the improvement of the programs, by increasing faculty participation and its commitment. However, it's always recommended to innovate and propose new assessment practices.

These strategies could be used as a guide for programs with same curriculum offered in different campuses but also can be adopted for classical one location instruction programs. In addition, these strategies can be used by non USA institutions with programs seeking accreditation with agencies similar to ABET such as Greater Caribbean Regional Engineering Accreditation System (GCREAS) which have continuous improvement as a criterion [8].

There are many commercial packages that provide solutions for assessment, however, if an institution use an educational platform, programs can implement these strategies at very low cost, allowing more faculty participation.

\section{ACKNOWLEDGMENT}

Authors acknowledge the Engineering Advisory Committee and all engineering faculty, students, alumni, administrators and staff from the Department of Engineering and Informatics Technology at Caribbean University who participate in the accreditation of the Civil and Electrical Engineering during cycle 2014-2015.

\section{REFERENCES}

[1] ABET, History. Available in: http://www.abet.org/about-abet/history/. Date of last access: February 22th, 2016.

[2] Aoudia, M., Abu Al-Qahsi, D.A.-D., "Development of a new curriculum for an industrial engineering program that meets the curriculum requirements of ABET and the institution," IEEE Global Engineering Education Conference (EDUCON), pp. 151-158, March 2015.

[3] ABET, Criteria for accrediting engineering programs: Effective for evaluations during the 2016-2017 Accreditation Cycle. http://www.abet.org/wp-content/uploads/2015/10/E001-16-17-EACCriteria-10-20-15.pdf/.

[4] Felder, R., Brent, R., "Designing and teaching courses to satisfy the ABET engineering criteria", Journal of Engineering Education, 92 (1): pp. 7-25, January 2003.

[5] Mourtos, N., "Integrating General Education Outcomes into a Senior Design Capstone Experience", IEEE International Conference on Interactive Learning (ICL), pp. 609-615, December 2014.

[6] Erradi, A., "easyCapstone: A framework for Managing and Assessing Capstone Design Projects", IEEE International Conference on Computer Science \& Education (ICCSE), pp. 1345-1350, July 2012.
[7] Yousafzai, J., Damaj, I., El-Abd, M., “A unified Approach for Assessing Capstone Design Projects and Student Outcomes in Computer Engineering Programs", IEEE Global Engineering Education Conference (EDUCON), pp. 333-339, March 2015.

[8] Manual y Formulario de Autoevaluación de un Programa de Ingeniería. Available in: www.caribengine.org/index.php/documents. Date of last access: February 22th, 2016.

14 ${ }^{\text {th }}$ LACCEI International Multi-Conference for Engineering, Education, and Technology: "Engineering Innovations for Global Sustainability", 20-22 July 2016, San José, Costa Rica. 